\title{
Analysis of Protection of Major Witness in Corruption Eradication Cases
}

\author{
Ismaidar \\ Faculty of Social Science, Universitas Pembangunan Panca Budi, Indonesia, Medan, North Sumatera
}

\begin{abstract}
Corruption has become massive societal phenomenon that has been regarded as extraordinary crimes threatening Indonesian economy and impeding national development. All societal elements expect that it will not be unresolved problems. Until recently, criminal law policy in its attempt to eradicate corruption has more put emphasis on the perpetrator. Such policy on witness protection, in the criminal case of corruption, needs to be optimized because it can be an alternative legal instrument in the attempt to eradicate corruption. Lawenforcement authorities face difficulties in unfolding a corruption case because it is often well systematically planned. In many cases, witnesses are reluctant to report a corruption case because of threat, intimidation, and criminalization posed to them. Problems are (1) How is the regulation of witness protection act and the corruption eradication in Indonesia? (2) How is the urgency of witness protection in the criminal cases of corruption eradication? (3) How is criminal law policy on witness protection to facilitate the corruption eradication in Indonesia? This research employs normative juridical approach with the descriptive research type. Findings show that (1) the development of witness protection act in the corruption case is highly relate to the witness stand on the criminal justice system; (2) the urgency of witness protection in the corruption eradication process is highly related to the common occurrence of intimidation and threat toward the witnesses. It indicates that the witness and victim protection is an important and urgent legal aspect; (3) criminal law policy in the corruption eradication process put more emphasis on the perpetrators and less concern on the witnesses involved in legal investigation. It is necessary to optimize the role of LPSK in criminal law policy
\end{abstract}

including in giving the protection to witness in the case of corruption eradication; therefore, it is important to conduct legal update on the witness protection act in the case of corruption eradication process.

Keywords: Witness Protection, Corruption Eradication, Criminal Law Policy

\section{INTRODUCTION}

Corruption has become a massive societal phenomenon prevalent in many places. It has been regarded as an extraordinary crime threatening the Indonesian economy and impeding national development. All societal elements expect that corruption will not be an unresolved problem. History has proven that almost every country is faced the problem of corruption (Prodjohamidjojo, 2002). If there is an official name of corruption eradication law, there are clear differences between the corruption eradication law and other criminal laws, such as the economic criminal act and the law on immigration crime.

There is a word of "controversy" that will associate our minds, which using the law, corruption can be eradicated, whereas it is proven in history, criminal prosecution and mere criminalization will not eradicate crime (Hamzah, 2002). As Thomas Moore (1478-1535) has pointed out, in 25 years, there were 72,000 thieves hanged in a region which has three to four million people, but crime continues to be rampant. According to Moore, violence will not stop the crime. To eradicate the crime, the cause must be found and eliminated 
(Boger, 1995). Therefore, a crime such as corruption will not be eradicated or diminished, unless we find the cause, so it will be able to prevent the crime.

In the process of corruption criminal justice in Indonesia, the existence of corruption law which already has very severe sanctions, and the existence of rules in corruption law that threaten corruption perpetrators with the death penalty. However, it cannot give a remarkable impact in eradicating corruption in Indonesia. Therefore, law enforcement such as police, prosecutor, and Corruption Eradication Commission (KPK), has faced great difficulties in unfolding corruption cases in Indonesia, even though the law has given unusual authority. However, in an attempt to disclose corruption cases, law enforcement still faces difficulties.

This is because the lack of individuals who want to report a corruption case, a lack of evidence of witness testimony will cause an unresolved corruption case. The case can be solved depending on the witnesses' testimony that has been successfully revealed. In the process of disclosing corruption cases, especially about the witness, many cases cannot be solved, because of the absence of witnesses who can support the task of law enforcement. The witness was reluctant to give testimony because of the threat, intimidation, and criminalization posed to them by the perpetrator (Hikmawati, 2013). Therefore, the witness has an important stand in the criminal justice system, including in criminal justice corruption.

The corruption eradication law and witness protection does not specifically explain the witness protection toward its role in disclosing corruption cases. Witness protection in the criminal justice corruption process is a matter of criminal law policy. The basic idea of witness protection is to facilitate and reinforce the criminal justice process by giving a sense of security to the witness in giving information in the criminal justice process. So, it can create an equitable trial to achieve material truth. Also, witness protection in criminal justice is a matter of criminal law, so criminal law policy is closely related to the regulation of witness protection (Irawan, 2016)

The concept of witnesses in Law 13 the Year 2006 as amended to Law Number 31 the Year 2014 should be expanded. It can be seen in the formulation of witness protection law in the legislature, preferring those who can be protected is limited to the witness family. Article 1 paragraph (7) of the Act describes who is meant by the witness family, namely person who has blood relation in a straight line up and down, and a line sideways to the third degree, or having a marital relationship with a witness and or person has a responsibility to witness and victim. This formulation is too narrow, the concept should relate to people who not only include the family, but it can include other people who have the potential to make witnesses who will not testify if the person is in intimidation (DPR RI, 2006).

According to Marc Ancel, a penal policy is an art that ultimately has a practical purpose to enable the rule of positive law to be formulated better and to provide guidance, not only to lawmakers but also to the courts that apply the law and also to the executors of court decisions. Then A. Mulder argues that the politics of the criminal law (Strafrecht Politiek) is to determine:

(a) How far the criminal provisions need to be changed or renewed,

(b) What can be done to prevent crime,

(c) How to investigate, to prosecute, judicial and criminal proceedings must be carried out.

The theory of criminal law policy is related to the issue of witness protection in eradicating corruption crime. If seen from the perspective of the theory, the study to be conducted in this research is the issue of witness protection as an alternative instrument of corruption eradication in Indonesia which is difficult to find the solution to eradicate. By maximizing the witness protection of corruption cases is 
expected it can be a solution to maximize corruption eradication in Indonesia. There are some problems that will be conducted in this research are:

(1) the issue of the regulation of the criminal law of witness protection in eradicating corruption crime,

(2) issue of the urgency of witness protection in the eradication of corruption crime, and

(3) criminal law to the witness protection as one of the instruments to eradicate corruption.

To answer the problems above, this article will discuss the urgency of witness protection as an alternative way to eradicate corruption. Besides, through existing facilities before such as penal and non-penal facilities in corruption crime, it also refers to a theory of legal policy criminal in eradicating corruption. So far, the criminal law policy in eradicating corruption crime is more emphasize the perpetrator, it can be seen in previous research results, some researches only examine how witness role in exposing corruption that can be used as an alternative instrument in eradicating corruption. There is an opportunity to optimize the witness protection, so disclosure of corruption cases in Indonesia will be optimal, which the criminal law policy is more put emphasis on the perpetrator in the eradication of corruption.

Related to the witness protection in eradicating corruption, Law no. 13 of 2006 jo Law no. 31 of 2014 on the Protection of Witnesses and Victims, Law no. 31 of 1999 on the Corruption Eradication, and Law no. 30 the Year 2002 on the Corruption Eradication Commission which became the reference for law enforcements in protecting witnesses in the criminal act of corruption. Meanwhile, the application stage and execution stage is how law enforcements apply provisions of Law no. 13 of 2006, Law no. 31 of 1999, and Law no. 30 of 2002 in protecting witnesses and whistleblower to provide information safely in the judicial process.

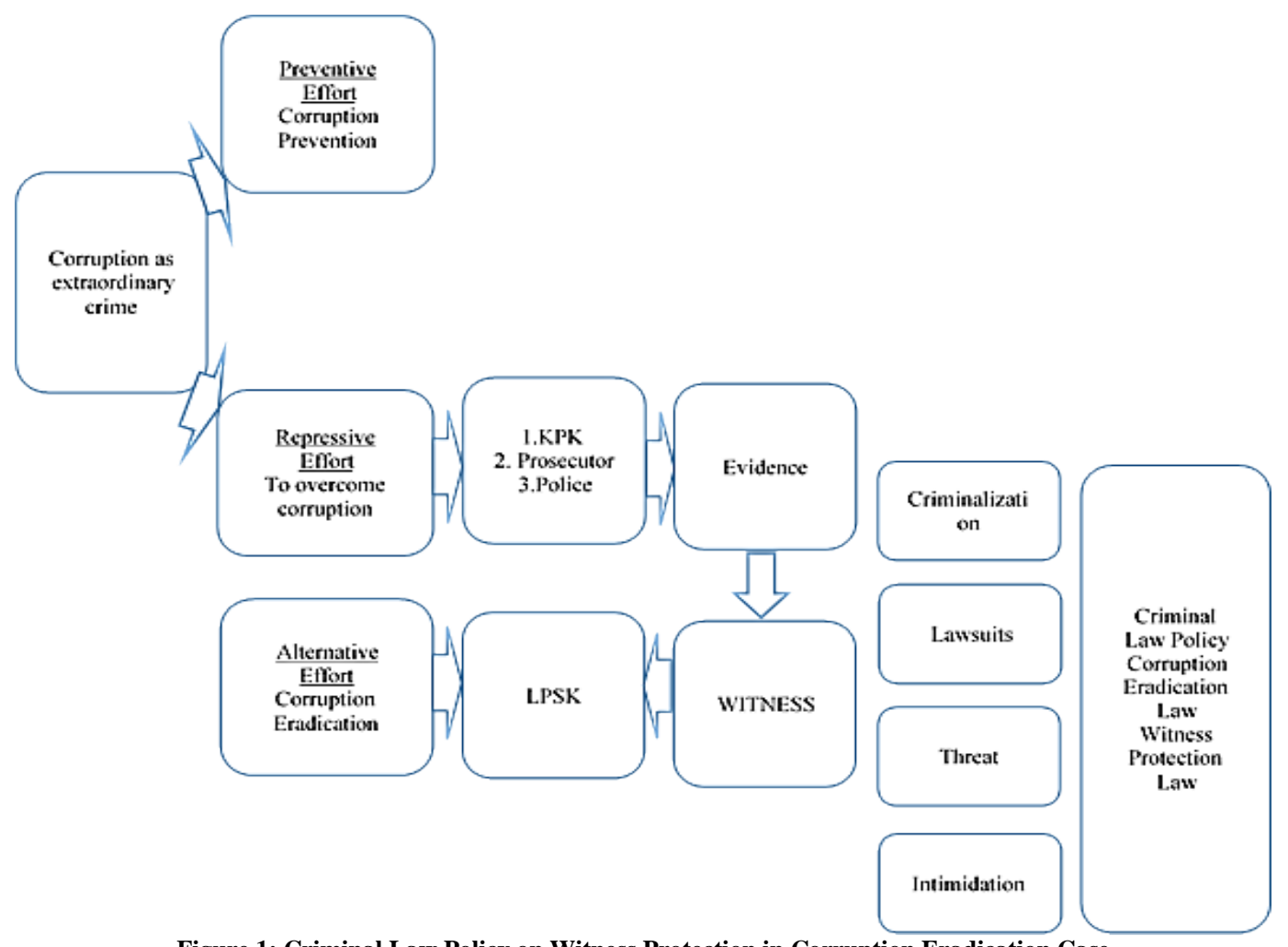

Figure 1: Criminal Law Policy on Witness Protection in Corruption Eradication Case

Based on the figure above, it is clear that a concrete legal rule that can accommodate the witness problem from the lawsuit is required. The existence of 
witnesses in corruption eradication are vulnerable to criminalization, intimidation, threatening, which are complex problems that must be solved. The witness protection law as a part of criminal law should be able to solve the problem of corruption crime, so witness protection in corruption eradication is very important. So, this article was intended (1) to find out, to analyze, and to explain how the regulation of witness protection act and the corruption eradication in Indonesia; (2) to find out, to analyze, and to explain how the urgency of witness protection in the criminal cases of corruption eradication; and (3) to find out, to analyze, and to explain how criminal law policy on witness protection to facilitate the corruption eradication in Indonesia.

\section{RESEARCH METHOD}

This research used doctrinal and non-doctrinal approach as a unity method. The research design was in the form of literature study and documentation which was analyzed normatively with legal interpretation and theoretical interpretation model by latent content analysis. This research was explorative which done by collecting various laws related to criminal law policy in witness protection as one of the instruments to prevent and eradicate corruption cases in Indonesia. Then the regulation was analyzed by normative juridical analysis. The data of this paper used include primary legal materials (binding materials), secondary legal materials (legal materials that explain primary legal materials). various doctrines (opinions of legal experts) related to the problem of corruption. The materials that have been collected are then analyzed using descriptive-analytical methods, to obtain an overview related to the existing problems.

\section{RESULT AND ANALYSIS}

\section{The Regulation of Witness Protection Act and the Corruption Eradication in Indonesia}

Witness protection is a part of the realization of a sense of security and it is a mandatory right that should be fulfilled. As an illustration, the criminal law policy is normatively stated in various laws and regulations such as the KUHP, KUHAP, and particularly criminal law. A criminal law policy that describes obligations of witness protection, even though it does include within the scope of witness protection as regulated in the witness protection law. The legal observer protection policy in the existing law has not accommodated yet witness protection in a corruption case, in the form of penal and non-penal policies and in the form of giving the rights to witnesses. To enforce the law against crimes act that can threaten the stand of witness and victim, there is special regulation on the witness and victim protection. This is because it involves highlevel economic and high-level beurocratic, indeed economic bureaucrats and government involving power, or perpetrators who threaten the stand of witness and victim (Adji, 2006).

\begin{tabular}{|l|l|c|}
\hline \multicolumn{3}{|c|}{ Table 1: The Regulation of Witness Protection Act and the Corruption Eradication } \\
\hline $\begin{array}{l}\text { UU } \\
\text { No. 13/2006 }\end{array}$ & Article 5, given same rights as KUHAP, in Article 10, obtains apenalty, & Given \\
\hline $\begin{array}{l}\text { UU } \\
\text { No.31/2014 }\end{array}$ & $\begin{array}{l}\text { Article 10, 1. toward witness, victim, justice collaborator, andwhistleblower, } \\
\text { cannot be prosecuted by civil /criminal, excepttestimony in good intention, } \\
\text { 2.postponement }\end{array}$ & $\begin{array}{l}\text { In stage begins. } \\
\text { isonly given tojustice collaborator }\end{array}$ \\
\hline $\begin{array}{l}\text { UU } \\
\text { No.31/1999 }\end{array}$ & $\begin{array}{l}\text { Article 31 (1) prohibition in mentioningwhistleblower identity } \\
\text { Article 35, Article 41 (2) e, public participation }\end{array}$ & $\begin{array}{l}\text { Participating public is required to have } \\
\text { legal protection }\end{array}$ \\
\hline $\begin{array}{l}\text { No. 20/2001 } \\
\text { UU }\end{array}$ & Issues of witnessprotection & Do not change thedescription in UU 31 \\
No. $\mathbf{3 0 / 2 0 0 2}$ & $\begin{array}{l}\text { Article 15, obligation of KPK to provides protection to witness and } \\
\text { whistleblower }\end{array}$ & Do not explain itsmechanism \\
\hline
\end{tabular}

In Indonesia, before the emergence of Law Number 13 of 2006 on Witness and Victim Protection, it has become a crucial matter, even intimidation and threats to witnesses are empirical experiences that often occurred (ICW, 2007). 
Various case reports released by several parties indicate that witness and victim protection is an important issue. Many witnesses and whistleblowers are reluctant to disclose information to law enforcement until in front of the court because of minimal guarantee.

Especially a guarantee of certain rights or certain mechanisms to testify. The lack of the guarantee resulted in unwilling witnesses to testify in court, whether in organized crime cases or other cases such as corruption, narcotics, and serious human rights violations, sexual crimes, trafficking, domestic violence, and other cases.

Furthermore, Abdul Haris Semendawai states that the emergence of Law No. 13 of 2006 on the witness and victim protection in Indonesia on 18 July 2006 was a significant development in reforming the criminal law system. Previously, in Indonesia, there were no regulations that specifically regulate witness and victim protection with systematic procedures, and mandate it into a particular institution that specifically provides witnesses and victims protection. However, in some countries witness protection give specifically mandate to protect intimidated witnesses, Law Number 13 the Year 2006 provides a larger mandate to LPSK such as giving support for victims of crime. Witness protection of organized crime cases does not receive adequate support from the law, as part of the witness protection policy in Indonesia.

An explanatory section of Law Number 13 the Year 2006 regarding witness and victim protection which is amended by Law Number 31 the Year 2014 is lexing specialize (special provisions) which regulates legal protection for witness and victim. Previously, arrangements and procedures for the protection of witnesses and victim were stated in several regulations and in some institutions which are given authority to provide protection. The explanation section of Law, no. 13 of 2006 on witness and victim protection stated:
"... in order to foster society participation in disclosing criminal acts, it is necessary to create a conducive circumstance by providing legal and safe protection to anyone who knows or finds something that can help revealing the crime that has occurred and report to the law enforcement. Furthermore, it is mentioned.... whistleblower should be provided adequate legal and safe protection for his/her report, so that he does not feel threat or intimidation..."

Regulations of legal protection for witness and victim in lex a specialist provides an understanding of unification of various provisions or legal protection procedures for witnesses which spread in positive law in Indonesia. Another understanding is Law No. 13 of 2006 on witness and victim protection can provide a legal basis for witness protection, but it isn't strong enough. It is concerning amendment of Law No. 13 of 2006 on witness and victim protection do not differentiate between protection and assistance to witness and victim. Practice in some countries, implementation of giving services between the witness protection unit and the units for crime victims are distinguished. The legal basis for witness protection and units for victims of crime (victim protection) has made difference between the witness, victim, or even whistleblower.

After the emergence of Law Number 31 Year 2014, two new terms have not been regulated in Law Number 13 the Year 2006 regarding witness and victim protection, namely the term of whistleblower and justice collaborator which collaborate with law enforcement. Before the emergence of Law number 31 the Year 2014, it was already set in SEMA Number 4 the Year 2011 but it is very minimum. No guidance can be used by law enforcement, so the existence of SEMA should be appreciated. SEMA as a transitional legal product greatly contributes to strengthening provisions of Article 10 paragraph (2) of Law no. 13 of 2006. At least some important things can be given to SEMA in protecting justice 
collaborators who work together (Eddyono, 2011). After the emergence of Law No. 31 of 2014, it has not been maximally protected witnesses, including the witness of corruption cases. We can see that many witnesses of corruption cases still get threats, intimidation, and criminalization after the emergence of the Law. This condition is not surprising that we will hear someone will be reluctant to be a witness in corruption cases (Setiawan, 2008).

A whistleblower is regulated in protection laws. Four articles regulate the protection of whistleblower, in general, namely: Article 1 paragraph (4) regarding the definition of whistleblower, Article 5 paragraph (3) concerning the right of witnesses and victims who also applies to the whistleblower, Article 10 provides for a criminal prosecution, and article 28 paragraph (3) requirements in giving protection by LPSK. Justice collaborator in this Law is regulated in the same article, although there are rules concerning justice collaborators who collaborate are regulated in Article 10 A paragraph (1) - (5). We can see that the regulation of witness protection is very minimum.

Also, witness protection matters are regulated in the corruption eradication act. Law Number 20 the Year 2001 regarding the amendment of Law Number 31 the Year 1999 concerning the Corruption Eradication. It explains about concept of witnesses in corruption cases which are specific rules of witness protection contained in this law. In Article 35 paragraph, the witness described as (1) the obligation to be the witness of the corruption case, that everyone must give testimony as a witness or expert, except father, mother, grandparent, sibling, wife or husband, and the grandson of the defendant. Also, the obligation to be a witness is regulated in Article 36 which states that the obligation to give testimony as regulated in Article 35 applies also based on job, dignity, or occupation are required to keep secrets, except for religious officers who believe they must keep secrets (Wiyono, 2011 ).
Corruption cases cause major disadvantages, but many corruption cases are not revealed. One of the reasons is the lack of witness testimony as evidence. The witness was reluctant to give testimony because he/she may be subject to threats or intimidation from the perpetrator. The existence of witnesses is very important in the criminal justice process. Therefore, to enforce and actualize the Witness and Victim Protection Agency as a medium for law enforcement in Indonesia is an activity that cannot be postponed for the law enforcement process and the development legal community of Indonesia (Soedarso, 2010). Furthermore, cases of corruption eradication, in the aspect of witness protection becomes determination in the process and the authority of the judge when making various judgments that are prerogative.

\section{The Urgency of Witness Protection in the Criminal Cases of Corruption Eradication in Indonesia}

In all stages of the settlement process of criminal cases, from the investigation stage until the verification stage in court, the stand of the witness is very important, even in practice, it often is a determining factor in disclosing a case, including in corruption cases (Iksan, 2011). Witness protection in corruption is very important, considering that in a criminal act of corruption, the suspect/defendant or related party can threaten a witness by using his / her position. The importance of witnesses' protection whistleblower has been stated in Article 31 Paragraph (1) of Law no. 31 In 1999 concerning corruption eradication, which states that, in investigation and examination stages in the court, witnesses and other persons which related to corruption are prohibited mention name or address of whistleblower or other matters which provide a possibility to know whistleblower identity.

A good government is a prerequisite for the realization of a democratic state which is aspired by all elements of the 
nation. It will be realized, if judicature is organized as the principles of justice, which respect the values of human rights, and it is in line with law enforcement processes, including the importance of witness protection. As mandated in Article 29 G Paragraph (1) of UUD 1945 which states that "Everyone has the right of selfprotection, family, honor, dignity, and property under his/her control, then he/she has the right of a sense of security and protection from the threat to do or do not do something which is called as a human right".

Law No. 8 of 1981 on Criminal Procedure Law has not provided certainty of adequate legal protection to witnesses who are informants of corruption case (whistleblower) as their juridical power, in Article 50 to Article 68 KUHAP only regulates protection toward suspects or defendants to be protected from various possibility violations of human rights. Whereas a witness is the most important asset in unfolding difficult corruption cases because from the witness, it can be obtained initial evidence which is used as the initial process to reveal the next corruption case.

The existence of a witness in a corruption case is a scary matter, so law enforcement faces difficulties in getting information from the witnesses. The scariest thing by a witness in revealing a corruption case is the possibility of a witness can be a suspect (criminalization) such as false accusations and defamation. We can see that based on documents collected by ICW and ELSAM, in 1999-2006, there were at least 39 witnesses and whistleblowers who were reported because of their testimonies with allegations of defamation and threats (Wisnubroto, 2007) and many more cases after the period. In August 2017, the print and electronic media were overwhelmed by the news of Johannes Marliem's death as one of the key witnesses of e-KTP corruption cases and his alleged death was related to his presence as a witness to the corruption case.
We can see that all norms in the Witness and Victim Protection Act should be included to protect witnesses, but threatening witnesses. It can be considered in Article 10 Paragraph (2) of Law No.13 of 2006, "A witness who is also a defendant in the same case cannot be exempted from criminal prosecution if it proves legally and convincingly. But his testimony can be used as a judge's consideration in relieving the criminal sanction imposed". Even if it cannot be said to threaten the existing Law, it can be considered that it is minim to accommodate the protection of witnesses, especially in the attempt of corruption eradication. The term pendulum has swung too far can at least illustrate that the criminal justice system in the issue of eradicating corruption has more put emphasis on suspects, defendants, convicted persons, but not yet put emphasis on the existence of a witness, as an important part of the criminal justice system.

The Criminal Law Policy on Witness Protection to Facilitate the Corruption Eradication in Indonesia, Criminal law policy is a part of legal politics, but the study of criminal law policy is more focused on criminal law. One form of criminal law politics is to design and to decide regulation on witness protection (Yuhermansyah, 2012). The criminal policy is a rational effort to eradicate crime. It is part of the law enforcement policy, which is part of social policy, the effort of society or state to improve the prosperity of society.

So far, the attention of policymakers and law enforcement has more emphasis on the perpetrators of criminal acts, but it is very less to witnesses and whistleblowers who have a role in exposing cases. There has been a law that specifically regulates witness protection, namely Law no. 13 of 2006 on the Protection of Witnesses and Victims. In the consideration of the Act, it is mentioned that this Act is necessary because of the importance of witness and victim's testimony as evidence in searching and finding clarity about criminal acts that committed by perpetrators, while law 
enforcement often faces difficulties to bring witnesses because of threats, whether physical or psychic threats from certain parties.

Before witness and victim protection law is legally used, the witness protection policy for certain crimes has been regulated in various laws and regulations. In these regulations, there are differences between parties who need protection. In human rights violations, for example, the protection of witnesses and victims is regulated in Article 4 of Government Regulation (PP) no. 2 of 2002 on Procedures for the Protection of Victims and Witnesses in Serious Human Rights Violations (implementing regulations of the provision of Article 34 paragraph (3) of Law Number 26 of 2000 on Human Rights Courts), the witnesses protection of money laundering crimes should be regulated in Article 5 of Government Regulation Number 57 of 2003 on special protection procedures for whistleblower and witnesses for money laundering crime (implementing regulation of the provisions of Article 40 paragraph (2) and Article 42 paragraph (2) of Law Number 15 Year 2002 regarding money laundering crime as amended by Law No. 25 of 2003), and the protection of witnesses of terrorism crime is regulated in Article 3 of Government Regulation Number 24 Year 2003 concerning procedures for protection of witnesses, investigators, prosecutors and judges in cases of terrorism crime (implementing regulations of Article 33 and Article 34 of Law Number 15 Year 2003 regarding Stipulation of Government Regulation in Lieu of Law Number 1 Year 2002 on eradication terrorism Crime, be a law). Particularly, in the case of corruption eradication, there is no specific regulation concerning witness protection of corruption cases.

Especially for corruption cases, witness protection is only regulated in Article 41 paragraph (2) letter e of Law Number 31 the Year 1999 concerning the corruption eradication, states that "the society who participate to assist the prevention and eradication of corruption can get legal protection, in the case of being asked to be present in investigation process in court as a whistleblower, witnesses, or expert witnesses which relevant to the provisions of applicable legislation”.

In addition, Law Number 30 the Year 2002 on the Corruption Eradication Commission also regulates the protection of witnesses. Article 15 states that "the Corruption Eradication Commission is obliged to protect witnesses or whistleblowers who submit reports or provide information about a corruption case." The implementation of the regulation of the provision on public participation in prevention and eradication of corruption is stated in PP No. 71 of 2000 on Procedures for implementation of public participation and awarding in the prevention and eradication corruption, it doesn't relate to the issue of witness protection. Article 5 paragraph (1) of the PP states that "everyone, social organization, or nongovernmental organization, providing information about alleged perpetrators of corruption, they can get legal protection both of legal and safe status." But, the protection is not provided, if there is sufficient evidence of investigation that strengthens the involvement of whistleblower in the reported corruption cases. It is also not provided if the whistleblower is the perpetrator in another case.

A. Mulder's states that criminal justice policy (Strafrecht Politiek) is the main policy to determine: (a) How far the right criminal provisions need to be changed or updated, (b) What can be done to prevent the occurrence of criminal acts (c) How to investigate, prosecute, judicial and criminal proceedings should be carried out. Issue of witness protection in the eradication of corruption case can be seen from the extent of the provisions of criminal law rules can be changed, so it can accommodate the issue of witness protection in eradicating corruption, so it can guarantee the existence of witnesses and can reveal many corruption 
cases from the previous situation which is difficult to unfold. Furthermore,

A. Mulder states that criminal law policy is related to what can be done to prevent the occurrence of criminal acts. Related to the issues that have been studied in this research, it can be found that one of the efforts to eradicate corruption that never be solved in Indonesia, then one way that can be done is to optimize the witness's protection in the corruption case. Optimizing witness protection can serve as the most effective solution to eradicate corruption in this country. The third opinion of the criminal justice policy theory based on A. Mulder's is it will be achieved when the two previous points can be run optimally.

Relevant to the theory of criminal law policy above, various existing laws and regulations which regulate witness protection are considered inadequate, so it is urgent to reform the Law which specifically regulates witness protection in eradicating corruption. Article 5 until Article 10 of the witness and victim protection law provides that various rights may be granted to a witness and a victim to provide a sense of security in providing information on any criminal justice process. These rights include: a. obtain protection for his or her personal, family, and property, and free from threats relating to testimony that he or she will be, or has given; b. participate in the process of selecting and determining the form of protection and safe support; c. provide information without being under pressure; d. got translator; e. free from trap questions; f. obtain information on case developments; g. obtain information on court decisions; h. knowing that the convicted person is released; i. get a new identity; j. get a new residence; $k$. obtain reimbursement of transportation costs as needed; l. get legal advice, and receive temporary living expenses to the end of the protection period.

The rights in witness protection law above are not sufficient, so it requires a systemic mechanism so that the witness protection in the context of corruption eradication can be realized, so it can reveal many corruption cases that are difficult to be unfolded. There should be a refinement of witness rights. The right of a witness should be regulated in detail, it should be distinguished between the right to be given to the witness in general regardless of the conditions, and the rights that are granted under special conditions. In the protection procedures, Articles 28-32 should be more detailed and complete. This article only explains how the witness obtains protection, engagement, and termination of protection, then provisions for witnesses to apply for support.

There is some limitation in giving witness protection, as stated in Article 28, protection is provided by considering: (a). The importance of witnesses and victims' testimony; (b). The level of threats that endanger the witness and victim; (c). The results of the medical team or psychologist's analysis toward witnesses were and victims; (d). Record of crimes that are ever committed by witnesses and victims Concerning the witness position that is important in unfolding corruption cases in the criminal law enforcement process, it is crucial to eliminate factors that make him/her reluctant to be a witness. As a consequence, it is required to provide legal guarantees that can provide protection and fulfillment of witness interests in the criminal justice system. The realization of a criminal law policy is not only through the roach of corruption perpetrators, but it also toward the witness of corruption cases. The existence of a witness protection law which mandates the protection of witnesses' rights to an institution called LPSK (Witness and Victim Protection Agency), it can perform duties and authorities if there is a request from a witness, it should be maximized by the existence of LPSK, it should not be passive but it must actively protect witnesses of corruption crime, which is considered to have an important role in unfolding a corruption case. 


\section{CONCLUSION}

The development of regulation on witness protection in corruption cases is inseparable from the stand of witness in the criminal justice system. Law enforcements in searching and finding clarity about criminal acts that committed by perpetrators, they often face difficulties for various reasons, such as the witness is afraid, worry, or even not able (lack of expense, depression, injury or even death). Therefore, it is necessary to provide protection for witnesses who are very important in corruption eradication. In Indonesia, before the emergence of Law No. 13 of 2006 on the Protection of Witnesses and Victims, it has been a lot of efforts in research because it has become a crucial matter, then practice of intimidation and threats to witnesses is an empirical experience that is often occurred. Various case reports which are released by some parties, it indicates that witness protection is an urgent issue. In its development, the regulation of witnesses and whistleblower in the Law on Protection of Witnesses and Victims of Law Number 13 Year 2006 does not recognize what is meant by whistleblower and justice collaborator including before the emergence of this Law, in Law No. 13 of 2006 provides a legal basis for LPSK to provide protection only to witnesses and victims. After the enactment of Law 31 Year 2014 on the Amendment of Law Number 13 Year 2006, then the terms of whistleblower and justice collaborator is used, but it does not maximally protect the existence of witnesses in the criminal justice system. Thus, it is important to conduct legal update on the witness protection act and expand witness protection mechanisms toward whistleblower and justice collaborator in corruption case, strengthening LPSK roles, strengthening LPSK authority which is no longer passive but should be active, the extension of protection services to whistleblower and justice collaborator, improving cooperation and institutional coordination, giving awards and special handling not only to the justice collaborator but also whistleblower, and then the regulation on the establishment of LPSK representatives in every province in Indonesia. Thus, the existence of witnesses in corruption cases can be maximized, so it can also maximize the corruption eradication in Indonesia.

\section{Acknowledgement: None}

\section{Conflict of Interest: None}

\section{Source of Funding: None}

\section{REFERENCES}

1. Adji, I.S. (2006). Korupsi Kebijakan Aparatur Negara Dan Hukum Pidana. Jakarta: CV Diadit Media.

2. DPR RI, „Hasil Panja Rancangan Undangundang Perlindungan Saksi“, Jakarta : DPR RI Pada Tanggal 12 Juli, 2006, p.45.

3. Eddyono, S.W, "Melihat Prospek Perlindungan "Pelaku yang Bekerjasama" di Indonesia”,Jurnal Lembaga Perlindungan Saksi dan Korban Vol.1 No.1, 2011, p.21.

4. Hamzah, A, "Sejak Zaman Nabi Musa Korupsi Sudah Ada”. Jakarta: Majalah Forum Keadilan, No.41, Februari, 2007

5. Hikmawati, P,“Upaya Perlindungan Whistleblower dan Justice Collaborator dalam Tindak Pidana Korupsi”. Jurnal Negara Hukum, Vol.4, No.1, Juni, 2013, p.88.

6. Iksan, M, "Kebijakan Legislatif Tentang Perlindungan Saksi Dalam Sistem Peradilan Pidana di Indonesia”,Jurnal Ilmu Hukum, Vol.14, No.2, September, 2011, pp.316-334.

7. Irawan, A, "Perlindungan Saksi Whistleblower dan Justice Collaborator Dalam Pemberantasan Tindak Pidana Korupsi”,Jurnal Alhuriyah, Vol.2, No.1, 2017, p.23.

8. Setiawan, M.A, "Urgensi Perlindungan Saksi dan Korban dalam Sistem Peradilan Pidana”,Jurnal Hukum dan Dinamika Masyarakat, Vol.5, No.2, April, 2008, p.133.

9. Soedarso, T, "Perlindungan Saksi dan Korban dalam Sistem Peradilan Pidana Indonesia”, Majalah Kesaksian-Media Perlindungan Saksi dan Korban, Jakarta: LPSK, edisi I Januari-Februari 2010, p.14. 
10. Wisnubroto, A, "Problematika dan Prospek Perlindungan Saksi dan Korban di Indonesia”, Jurnal Hukum Pro Justisia, Vol.25, No.1, Januari, 2007, pp.73-75.

11. Wiyono,R. (2011). Pembahasan Undangundang Pemberantasan Tindak Pidana Korupsi, Jakarta,Sinar Grafika.

12. Yuhermansyah, E, "Urgensi Perlindungan Saksi Berdasarkan Undang-Undang Nomor
13 Tahun 2006”,Jurnal Legitimasi Vol.1, No.2, Januari-Juni, 2012 pp.212-

How to cite this article: Ismaidar. Analysis of protection of major witness in corruption eradication cases. International Journal of Research and Review. 2021; 8(11): 78-88. DOI: https://doi.org/10.52403/ijrr.20211110 